\title{
ANALISIS YURIDIS UPAH PEKERJA DALAM PROSES PEMUTUSAN HUBUNGAN KERJA BERDASARKAN PUTUSAN HAKIM
}

\author{
Junan Gunawan Panjaitan* \\ PT. Foster Electrik Indonesia
}

\begin{abstract}
In industrial relations, the elements involved should play their roles and functions properly, creating harmonious relationships that can stimulate economic growth. So the aim of this research is to know the interpretation of Law No. 13 Year 2003 concerning Manpower against the wages of workers / laborers under process during termination. In this case the author conducted this study using a normative juridical approach. The judge's decision that provides 6 (six) months of process wages or more is based on the theory of legal justice, namely the thought that the decision-making process based on both parties justice consideration. The judges' decisions provide zero process wages in accordance with theory progressive law which considers the benefit of both parties, namely labors and employers and development of one area in particular and national in general.
\end{abstract}

Keywords: Process Wages, Labors/Employes, Verdict.

\begin{abstract}
Abstrak
Di dalam hubungan industrial, unsur yang terlibat dituntut dapat memerankan peran dan fungsinya dengan baik, sehingga tercipta hubungan yang harmonis yang pada akhirnya akan menggairahkan perkembangan ekonomi. Tujuan penelitian ini untuk mengetahui tafsiran Undang-Undang No 13 Tahun 2003 tentang Ketenagakerjaan terhadap upah Pekerja/Buruh yang mengalami proses Pemutusan Hubungan Kerja. Dalam hal ini Peneliti menggunakan pendekatan yuridis normatif. Putusan Hakim yang memberikan upah proses sebanyak 6 (enam) bulan upah atau lebih didasari oleh teori keadilan hukum, yaitu pemikiran bahwa proses penjatuhan putusan dilakukan secara adil bagi kedua belah pihak yaitu Pengusaha dan Pekerja/Buruh. Sedangkan, putusan Hakim yang tidak memberikan upah proses didasari oleh teori hukum progresif, yaitu pemikiran yang lebih mengutamakan kepentingan yang lebih luas dalam mengembangkan ekonomi didaerah secara khusus dan nasional secara umum.

Kata Kunci : Upah Proses, Pekerja/Buruh, Putusan.
\end{abstract}

\footnotetext{
*Alamat Korespondensi : gnw@foster.com.sg
} 


\section{A. Latar Belakang Masalah}

Pengusaha dan Pekerja/Buruh memiliki peran sentral dalam menjalankan perusahaan. Keharmonisan hubungan para pihak menjadi salah satu kunci utama dalam menjaga roda industri agar bisa berjalan secara baik. Perusahaan membutuhkan karyawan untuk menjalankan dan menghasilkan barang produksi. Karyawan juga membutuhkan perusahaan agar mereka dapat bekerja dan sebagai imbalan atas jasa yang mereka berikan, maka mereka mendapatkan upah.

Upah yang diberikan oleh perusahaan kepada Pekerja/Buruh dan jasa yang diberikan oleh Pekerja/Buruh kepada perusahaan menimbulkan hubungan hukum diantara keduanya. Hubungan hukum yang terjalin diantara Pengusaha dan Pekerja/Buruh selanjutnya lebih dikenal dengan istilah Hubungan Industrial. Pada tahun 2004 Pemerintah setelah mendapat persetujuan Dewan Perwakilan Rakyat juga mengeluarkan Undang-Undang No 2 Tahun 2004 tentang Penyelesaian Perselisihan Hubungan Industrial. Dari sekian pasal-pasal dalam Undang-Undang tersebut, baik Undang-Undang Nomor 13 Tahun 2003 maupun Undang-Undang No 2 Tahun 2004, Peneliti dalam pembuatan Tesis ini tertarik untuk menelaah lebih dalam Pasal 155 Undang-Undang No 13 Tahun 2003 tentang Ketenagakerjaan yang didalamnya mengatur upah terhadap Pekerja/Buruh yang mengalami proses Pemutusan Hubungan Kerja.

Undang-Undang ini dikeluarkan melihat kondisi ketenagakerjaan nasional yang serius dan perlu suatu pengaturan perlindungan tehadap Pekerja/Buruh itu sendiri dan juga pembatasan-pembatasan terhadap Pengusaha sehingga tercipta hubungan industrial yang harmonis demi terciptanya kebangkitan ekonomi nasional.

Permasalahan ketenagakerjaan apabila tidak dapat diselesaikan dengan mediasi dan konsiliasi, maka tingkat penyelesaian akhir dari permasalahan tersebut adalah di pengadilan yang disebut dengan Pengadilan Hubungan Industrial. Undang-Undang Nomor 2 Tahun 2004 tentang Penyelesaian Perselisihan Hubungan Industrial (selanjutnya disebut UU PPHI) lahir menjadi dasar hukum dari pembentukan untuk menjadi institusi penyelesaian perselisihan hubungan industrial yang cepat, tepat, dan adil. Di pengadilan hubungan industrial diharapkan didapat suatu penyelesaian yang mengikat yang harus dipatuhi kedua belah pihak yang bertikai, baik itu Pengusaha maupun Pekerja/Buruh sehingga dicapai penyelesaian yang adil bagi kedua belah pihak, walaupun pengertian keadilan itu sendiri sangat subjektif.

Perselisihan Hubungan Industrial adalah perbedaan pendapat yang mengakibatkan pertentangan antara Pengusaha atau gabungan Pengusaha dengan Pekerja/Buruh atau Serikat Pekerja/Serikat Buruh karena adanya perselisihan mengenai hak perselisihan kepentingan, perselisihan pemutusan 
hubungan kerja dan perselisihan antar Serikat Pekerja/Serikat Buruh dalam satu perusahaan. ${ }^{1}$

Dalam praktiknya, hubungan industrial tidak selalu berjalan mulus sebagaimana yang diharapkan kedua belah pihak, seperti terjadinya Pemutusan Hubungan Kerja (PHK) yang mempunyai konsekuensi juga terhadap upah Pekerja/Buruh yang sedang dalam proses pemutusan hubungan kerja. Perselisihan pemutusan hubungan kerja merupakan perkara yang sering terjadi di Pengadilan Hubungan Industrial Tanjung Pinang. Dalam pelaksanannya, tidak jarang para pihak yang berselisih merasa tidak puas dengan putusan yang dibuat oleh Hakim-Hakim di Pengadilan Hubungan Industrial Tanjung Pinang. Sehingga diantara mereka ada yang melaksanakan upaya hukum kasasi ke Mahkamah Agung dan tidak jarang putusan Hakim Mahkamah Agung berbeda dengan putusan yang diberikan oleh Hakim di Pengadilan Hubungan Industrial Tanjung Pinang.

Putusan pengadilan tidak terlepas dari keadilan yang diberikan Hakim. Keadilan yang dimaksud disini adalah keadilan bagi semua pihak. Walaupun sangat susah untuk mendefinisikan keadilan itu sendiri. Adil menurut pihak yang memenangkan perkara belum tentu adil bagi pihak yang kalah dalam perkara.

Hakim juga dalam memutus suatu perselisihan tidak terlepas dari aliran teori hukum mana yang dianutnya. Hal ini dapat jelas terlihat dari jenis putusan yang dikeluarkan. Dari putusan yang dikeluarkan oleh Hakim dapat ditarik kesimpulan apakah Hakim yang memutus perkara menganut teori keadilan hukum ataukah teori hukum progresif atau aliran teori hukum lainnya.

Peneliti yang selama karirnya berkecimpung dalam praktisi sumber daya manusia menemukan adanya putusan Hakim Mahkamah Agung yang berbeda-beda terhadap upah Pekerja/Buruh yang mengalami Pemutusan Hubungan Kerja. Oleh karena itu, Peneliti mengambil judul dalam penelitian ini adalah "ANALISIS YURIDIS UPAH PEKERJA DALAM PROSES PEMUTUSAN HUBUNGAN KERJA BERDASARKAN PUTUSAN HAKIM."

\section{B. Perumusan Masalah}

Bila ditelusuri pada putusan Hakim Mahkamah Agung tentang upah Pekerja/Buruh yang mengalami Pemutusan Hubungan Kerja, maka dirumuskan permasalahan penelitian sebagai berikut:

1. Bagaimanakah tafsiran Undang-Undang No 13 Tahun 2003 tentang Ketenagakerjaan terhadap upah Pekerja/Buruh yang mengalami proses Pemutusan Hubungan Kerja?

\footnotetext{
${ }^{1}$ Pasal 1 ayat 1 Undang-Undang Nomor 2 Tahun 2004 Tentang Penyelesaian Perselisihan Hubungan Industrial, Tambahan Lembaran Negara Republik Indonesia Nomor 4279
} 
2. Mengapa ada putusan Hakim yang berbeda-beda terhadap upah proses dan teori hukum apa yang dianut oleh Hakim dalam memberikan putusan terhadap upah proses?

3. Dari putusan Hakim terhadap upah proses yang berbeda-beda tersebut, putusan yang mana yang memenuhi unsur keadilan?

\section{Metode Penelitian}

Rancangan penelitian berisi pokok-pokok perencanaan seluruh penelitian yang tertuang dalam suatu kesatuan naskah secara ringkas, jelas dan utuh. Dalam hal ini Peneliti dalam melakukan penelitian ini menggunakan pendekatan yuridis normatif. Penelitian yuridis normatif disebut juga dengan penelitian hukum doktrinal karena penelitian ini dilakukan atau ditujukan hanya kepada peraturan-peraturan yang tertulis dan bahan hukum yang lain. Penelitian hukum ini juga disebut sebagai penelitian kepustakaan ataupun studi dokumen karena penelitian ini lebih banyak dilakukan terhadap data yang bersifat sekunder yang ada diperpustakaan. ${ }^{2}$

Penelitian ini menggunakan bahan hukum primer yang merupakan bahan-bahan hukum yang didapat dari peraturan perundang-undangan yang ada hubungannya dengan permasalahan penelitian, seperti Undang-Undang Dasar Negara Republik Indonesia tahun 1945, Kitab Undang-Undang Hukum Perdata, Undang-Undang Nomor 13 Tahun 2003 tentang Ketenagakerjaan, Undang-Undang Nomor 2 Tahun 2004 tentang Perselisihan Hubungan Industrial, Keputusan Menteri Tenaga Kerja nomor:KEP-150/MEN/2000 tentang penyelesaian pemutusan hubungan kerja dan penetapan uang pesangon, uang penghargaan masa kerja dan ganti kerugian di perusahaan, Putusan Hakim Mahkamah Agung Nomor 04 /Pdt.Sus PHI/2014/PN.Pbr yang melibatkan antara Hansen Sinaga melawan CV Pajero Motor, Putusan Hakim Mahkamah Agung Nomor 432 K/Pdt.Sus-PHI/2014 yang melibatkan antara Muhammad Hidayat melawan DPD Gapeksindo dan Putusan Hakim Mahkamah Agung Nomor 70 K/Pdt.Sus/2013 yang melibatkan antara Elti Aryani melawan PT Resati Putra Indah

Disamping bahan hukum primer, bahan hukum sekunder juga dibutuhkan. Bahan Hukum Sekunder adalah bahan-bahan yang juga diperlukan dan dapat memberikan penjelasan mengenai bahan hukum primer seperti buku-buku, makalah, majalah, jurnal, laporan hasil penelitian, dan karya ilmiah lainnya yang berhubungan dengan obyek penelitian. Buku-buku yang digunakan dalam penelitian ini antara lain adalah buku C.S.T Kansil dengan judul Pengantar Ilmu Hukum dan Tata Hukum Indonesia, Mahfud MD dengan judul Politik Hukum di Indonesia, Padmo Wahono dengan judul Indonesia Negara Berdasatkan atas hukum, Janus Sidabalok dengan judul Hukum

\footnotetext{
${ }^{2}$ Bambang Sunggono, Metode Penelitian Hukum, Jakarta: Rajagrafindo Persada, 2007, hal 81
} 
Perusahaan, Analisis Terhadap Pengaturan Peran Perusahaan Dalam Pembangunan Ekonomi Nasional Di Indonesia.

Bahan hukum tersier diperlukan untuk melengkapi informasi bahan hukum Primer dan Sekunder seperti: Kamus Hukum, Kamus Besar Bahasa Indonesia (KBBI), Kamus Bahasa Inggris, Ensikopedia, dan lain-lain. Kamus yang digunakan sebagai referensi dalam penelitian ini adalah Kamus Besar Bahasa Indonesia (KBBI).

Dalam teknik pengumpulan data, peneliti menggunakan teknik pengumpulan data dengan cara studi kepustkaan. Hal tersebut dilakukan dengan mempelajari dan mengumpulkan dokumen-dokumen, baik itu buku-buku, peraturan-peraturan, putusan Hakim Mahkamah Agung dan literatur yang berhubungan dengan penelitian ini. Dokumen-dokumen tersebut membantu Peneliti dalam menganalisa putusan yang diambil dan menghubungkannya dengan teori hukum mana yang mempengaruhi Hakim sehingga Hakim mengambil sebuah putusan yang berbeda-beda seperti upah proses sebesar 6 (enam) bulan atau lebih dan tidak memberikan upah proses.

Setelah pengumpulan data selesai, kemudian data diolah dengan melakukan analisis. Metode pengumpulan data dilakukan dengan cara penelitian kepustakaan (library research), yaitu penelitian yang dilakukan dengan cara meneliti bahan pustaka atau yang disebut data sekunder. ${ }^{3}$

Analisis data digunakan untuk menyederhanakan data ke dalam bentuk yang lebih mudah dibaca. Semua data yang diperoleh kemudian dianalisis dengan menggunakan analisis kualitatif. Analisis kualitatif artinya menguraikan data secara bermutu dalam bentuk kalimat yang teratur, runtun, logis, tidak tumpang tindih, dan efektif, sehingga mempermudah interprestasi data dan pemahaman hasil analisis. ${ }^{4}$

Penelitian kepustakaan yang dilakukan adalah membandingkan peraturan-peraturan, ketentuan-ketentuan, dan buku referensi, serta data yang diperoleh, kemudian dianalisis secara kualitatif yang akan memberikan gambaran menyeluruh tentang aspek hukum yang berhubungan dengan masalah yang akan diteliti. Data yang diperoleh dalam penelitian ini dianalisis secara yuridis kualitatif dengan menggunakan metode berpikir deduktif (umum-khusus),

Analisis data dilakukan secara bertahap, sehingga kekurangan data penelitian secepatnya dapat diketahui dan sesegera mungkin dilengkapi dengan melakukan penelitian ulang guna pengambilan data tambahan untuk melengkapi kekurangan data tersebut. ${ }^{5}$ Analisis mengenai permasalahan yang diangkat dalam penelitian ini, dilakukan berkaitan dengan adanya kesenjangan antara hukum normatif (das sollen) dengan pelaksanaan norma-norma hukum (das sein) di dalam putusan Hakim. Putusan Hakim ini sangat essensial baik bagi para Pekerja/Buruh maupun Pengusaha dalam hal mencari keadilan.

\footnotetext{
${ }^{3}$ Soerjono Soekanto, Pengantar Penelitian Hukum, Jakarta: UI Press, 1986, hal 24

${ }_{5}^{4}$ Amiruddin, Pengantar Metode Penelitian Hukum, Jakarta: PT Raja Grafindo Persada, 2012, hal 34

${ }^{5}$ Ibid, hal 112
} 


\section{Hasil Penelitian Dan Pembahasan}

Perselisihan hubungan industrial adalah perbedaan pendapat yang mengakibatkan pertentangan antara Pengusaha atau gabungan Pengusaha dengan Pekerja/Buruh atau Serikat Pekerja/Serikat Buruh karena adanya perselisihan mengenai hak, perselisihan kepentingan perselisihan pemutusan hubungan kerja serta perselisihan antar Serikat Pekerja/Serikat Buruh hanya dalam satu perusahaan.

Selama ada hubungan industrial, perselisihan ini sering terjadi, baik perselisihan yang bisa diselesaikan secara bipartit, tripartit ataupun berakhir dipengadilan. Pada saat perselisihan sudah bergulir dipengadilan maka para pihak yang berselisih harus mengikuti prosedur peradilan yang berlaku.

Perselisihan pemutusan hubungan kerja adalah perselisihan yang timbul karena tidak adanya kesesuaian pendapat mengenai pengakhiran hubungan kerja yang dilakukan oleh salah satu pihak. Para pihak yang tetap pada pendiriannya walaupun sudah diusahakan berbagai cara agar tercapai win win solution, maka dibutuhkanlah pihak ketiga. Dipengadilanlah diharapkan ditemukan suatu penyelesaian yang berkeadilan.

Pada saat seorang Pekerja/Buruh dipandang oleh Pengusaha tidak dibutuhkan lagi karena melakukan suatu perbuatan yang dianggap melanggar ketentuan sebagaimana diatur dalam perjanjian kerja, peraturan perusaahaan atau perjanjian kerja bersama dan diputus hubungan kerjanya, maka saat itulah status Pekerja/Buruh tersebut dipertanyakan. Sebagai Pengusaha yang menjalankan usaha (business) tidak akan mau dibebankan oleh biaya-biaya (unproductive expense) dari akibat proses pemutusan hubungan kerja. Pengusaha menganggap bahwa pada saat Pekerja/Buruh diputus hubungan kerjanya, pada saat itulah kewajiban Pengusaha untuk membayar upah beserta tunjangan yang setiap bulan lazimnya diterima Pekerja/Buruh berhenti. Dan bahkan Pengusaha tidak mau lagi Pekerja/Buruh berada dilingkungan perusahaan karena dikwatirkan Pekerja/Buruh berbuat sesuatu yang merugikan Pengusaha. Sebaliknya Pekerja/Buruh menganggap bahwa pemutusan hubungan kerja sepihak yang dilakukan oleh Pengusaha merupakan bencana bagi Pekerja/Buruh itu sendiri. Disamping Pekerja/Buruh itu sendiri mencukupi dirinya dan juga keluarganya bila Pekerja/Buruh itu sudah berumah tangga.

Selama pemutusan hubungan kerja belum ditetapkan oleh pengadilan hubungan industrial (Pasal 155 ayat 2 Undang-Undang Nomor 13 Tahun 2003 tentang Ketenagakerjaan), maka Pekerja/Buruh mengharapakan hak-hak yang setiap bulannya diterima Pekerja/Buruh dari Pengusaha. Upah yang seharusnya diberikan selama proses pemutusan hubungan kerja sampai mendapatkan penetapan lembaga 
penyelesaian hubungan industrial, Peneliti menggunakan istilah "upah proses". Selama belum ada penetapan dari Pengadilan Hubungan Industri, Pekerja/Buruh masih berharap dapat bekerja sebagaimana biasanya dan mendapatkan upah sebagaimana yang Pekerja/Buruh dapatkan setiap bulannya

Untuk membuat sebuah penelitian menjadi terarah maka diperlukan landasan teori yang dikutip dari para ahli hukum. Teori hukum ini sangat dibutuhkan dalam menganalisa apakah penelitian yang dilakukan masih relevan dengan objek yang akan diteliti sehingga objek yang diteliti bisa menjadi lebih jelas dan lebih memuaskan. Teori yang dikutip adalah Teori Keadilan Hukum menurut I Dewa Gede Atmadja yang menyatakan bahwa keadilan itu terletak pada tuntutan bahwa putusan harus dihasilkan berdasarkan penerapan aturan umum. Keadilan adalah penerapan hukum dengan cara yang benar. Hukum itu adil bila dapat mencerminkan keadilan bagi semua orang. Hakim dalam konteks ini tidak hanya menafsirkan sebuah perkara secara legal, tetapi juga apa yang baik bagi kemanusiaan. ${ }^{6}$

Teori hukum yang dikutip selanjutnya adalah teori hukum progresif. istilah hukum progresif di sini adalah istilah hukum yang diperkenalkan oleh Satjipto Rahardjo, yang dilandasi asumsi dasar bahwa hukum adalah untuk manusia. Satjipto Rahardjo merasa prihatin dengan rendahnya kontribusi ilmu hukum dalam mencerahkan bangsa Indonesia, dalam mengatasi krisis, termasuk krisis dalam bidang hukum itu sendiri. Untuk itu beliau melontarkan suatu pemecahan masalah dengan gagasan tentang hukum progresif.

Adapun pengertian hukum progresif itu sendiri adalah mengubah secara cepat, melakukan pembalikan yang mendasar dalam teori dan praksis hukum, serta melakukan berbagai terobosan. Pembebasan tersebut didasarkan pada prinsip bahwa hukum adalah untuk manusia dan bukan sebaliknya dan hukum itu tidak ada untuk dirinya sendiri, melainkan untuk sesuatu yang lebih luas yaitu untuk harga diri manusia, kebahagiaan, kesejahteraan, dan kemuliaan manusia. ${ }^{7}$

Hukum progresif dapat diartikan bahwa hukum itu peduli kepada kemanusiaan dan bukan hanya normatif dalam pengertian sempit. Dalam perkataan lain hukum progresif dapat juga disebut sebagai hukum yang lebih berpihak kepada rakyat dan hukum yang berkeadilan. Konsepnya sendiri adalah hukum itu bukan untuk kepentingannya sendiri, melainkan untuk suatu tujuan yang berada di luar dirinya dalam pengertian yang lebih luas.

Dalam pelaksaannya hubungan industrial dapat menimbulkan gesekan dan permasalahan yang menggangu ketidakharmonisan hubungan antara Pekerja/Buruh dan Pengusaha. Adanya gesekan dan permasalahan tersebut dapat menggangu produktifitas, sehingga bisa mengarah kepada pemutusan hubungan kerja. Sejauh mungkin pemutusan hubungan kerja harus dihindarkan karena pemutusan hubungan kerja adalah awal dari bencana bagi Pekerja/Buruh itu sendiri. Tetapi adakalanya

\footnotetext{
${ }^{6}$ I Dewa Gede Atmadja, Filsafat Hukum, Jakarta : Setara Press, hal 81

${ }^{7}$ Satjipto Rahardjo, Membedah Hukum Progresif, Jakarta: Kompas, 2007, hal 154
} 
pemutusan hubungan kerja tetap dilaksanakan manakala segala upaya telah dilaksanakan tetapi tidak menemui penyelesaian.

Hubungan kerja yang terjalin antara pekerja dengan Pengusaha didasari oleh kesepakatan yang dituang dalam sebuah perjanjian. Perjanjian yang dibuat oleh para pihak harus disesuaikan dengan Pasal 52 ayat (1) Undang-Undang Nomor 13 Tahun 2003 tentang Ketenagakerjaan. Perjanjian kerja dibuat atas dasar :

1. Kesepakatan kedua belah pihak

2. Kemampuan atau kecakapan melakukan perbuatan hukum

3. Adanya pekerjaan yang diperjanjikan dan

4. Pekerjaan yang diperjanjikan tidak bertentangan dengan ketertiban umum, kesusilaan dan peraturan perundang-undangan yang berlaku

Konsep perjanjian kerja tersebut diselaraskan dengan ketentuan Kitab Undang Undang Hukum Perdata (KUHPerdata) dalam Pasal Pasal 1320 KUHPerdata mengenai syarat sahnya suatu perjanjian yaitu :

1. Adanya kesepakatan kedua belah pihak.

2. Kecakapan untuk melakukan perbuatan hukum

3. Adanya obyek.

4. Adanya kausa yang halal.

Adanya hubungan kerja harus didasari oleh suatu perjanjian kerja dan berakhirnya suatu perjanjian kerja juga harus berdasarkan waktu yang disepakati di dalam perjanjian kerja. Oleh karena itu pengakhiran perjanjian kerja yang belum pada waktunya sebagaimana yang diperjanjikan harus mendapatkan kesepakatan kedua belah pihak. Pemutusan hubungan kerja yang terjadi dapat diinisiasi oleh Pengusaha maupun Pekerja/Buruh. Pemutusan hubungan kerja yang tidak didasari oleh kesepakatan, maka akan memunculkan perselisihan antara Pekerja/Buruh dengan Pengusaha. Pada praktiknya, Pengusaha sering melakukan pemutusan hubungan kerja secara sepihak, sehingga melahirkan perselisihan.

Dari segi Pengusaha, pemutusan hubungan kerja dapat terjadi karena banyak pertimbangan-pertimbangan seperti Pekerja/Buruh melanggar tata tertib perusahaan, Pekerja/Buruh sudah dianggap tidak produktif lagi. Akibat dari pemutusan hubungan kerja tersebut dapat menimbulkan implikasi yang berbeda-beda yaitu implikasi perselisihan hak dan juga kepentingan. Adanya perselisihan tersebut mengakibatkan baik Pekerja/Buruh ataupun Pengusaha tidak bisa saling menerima alasan-alasan yang disampaikan oleh para pihak.

Menurut Pasal 151 ayat 1 UU Ketenagakerjaan, dalam melakukan PHK, Pengusaha, Pekerja/Buruh, serikat pekerja/serikat buruh, dan Pemerintah, dengan segala upaya harus mengusahakan agar jangan terjadi pemutusan hubungan kerja. Dalam Pasal 151 ayat 2 UU Ketenagakerjaan juga dijelaskan bahwa dalam hal upaya telah dilakukan, tetapi pemutusan hubungan kerja tidak dapat dihindari, maka maksud pemutusan hubungan kerja wajib dirundingkan oleh Pengusaha dan serikat pekerja/serikat buruh atau dengan Pekerja/Buruh apabila 
Pekerja/Buruh yang bersangkutan tidak menjadi anggota serikat pekerja/serikat buruh.

Pengakhiran hubungan kerja yang terjadi akan mengakibatkan berakhirnya hak dan kewajiban antara Pekerja/Buruh dengan Pengusaha, tetapi tidak menutup kemungkinan dalam hal terjadinya pemutusan hubungan kerja akan menimbulkan perselisihan antara Pekerja/Buruh dengan Pengusaha dengan berbagai alasan seperti pemutusan hubungan kerja tersebut tidak disepakati oleh salah satu pihak.

Perselisihan pemutusan hubungan kerja yang terjadi antara Pengusaha dengan Pekerja/Buruh, dapat ditempuh upaya hukum yang dapat dilakukan oleh Pekerja/Buruh untuk melindungi hak-haknya sebagai akibat adanya pemutusan hubungan kerja tersebut. Upaya hukum yang dapat ditempuh oleh Pekerja/Buruh untuk menyelesaikan perselisihan pemutusan hubungan kerja tersebut adalah melalui jalur pengadilan (litigasi) yaitu melalui pengadilan hubungan industrial atau dapat diselesaikan diluar pengadilan hubungan industrial (non litigasi). Pemutusan hubungan kerja yang terjadi terhadap Pekerja/Buruh menimbulkan hak dan kewajiban. Pasal 155 ayat 2 UU No 13 Tahun 2003 tentang Ketenagakerjaan mengatakan bahwa "Selama putusan lembaga penyelesaian perselisihan hubungan industrial belum ditetapkan, baik Pengusaha maupun Pekerja/Buruh harus tetap melaksanakan segala kewajibannya". Dari pasal tersebut dapat diketahui bahwa sebelum adanya putusan pengadilan yang berkekuatan hukum tetap, Pengusaha harus tetap melaksanakannya kewajibannya seperti memberikan upah kepada Pekerja/Buruh, begitu juga dengan Pekerja/Buruh juga harus melaksanakan kewajibannya seperti bekerja.

Hal tersebut dikuatkan oleh Putusan MK No 37 /PUU-IX/2011 yang menyatakan bahwa frase "belum ditetapkan" dalam Pasal 155 ayat 2 UU No 13 Tahun 2003 tentang Ketenagakerjaan bertentangan dengan Undang-Undang Dasar Negara Republik Indonesia Tahun 1945 sepanjang tidak dimaknai belum berkekuatan hukum tetap.

Putusan MK No 37/PUU-IX/2011 tersebut berbunyi sebagai berikut :

1. Frasa "belum ditetapkan" dalam Pasal 155 ayat (2) Undang-Undang Nomor 13 Tahun 2003 tentang Ketenagakerjaan (Lembaran Negara Republik Indonesia Tahun 2003 Nomor 39, Tambahan Lembaran Negara Republik Indonesia Nomor 4279) adalah bertentangan dengan Undang Undang Dasar Negara Republik Indonesia Tahun 1945 sepanjang tidak dimaknai belum berkekuatan hukum tetap

2. Frasa belum ditetapkan dalam Pasal 155 ayat (2) Undang-Undang Nomor 13 Tahun 2003 tentang Ketenagakerjaan (Lembaran Negara Republik Indonesia Tahun 2003 Nomor 39, Tambahan Lembaran Negara Republik Indonesia Nomor 4279) tidak mempunyai kekuatan hukum mengikat sepanjang tidak dimaknai belum berkekuatan hukum tetap 
3. Memerintahkan pemuatan putusan ini dalam Berita Negara Republik Indonesia sebagaimana mestinya

Dari isi putusan MK tersebut dapat ditarik kesimpulan yang menguatkan bahwa upah proses harus diberikan seperti sebagaimana yang terdapat dalam isi Pasal 155 ayat (2) UU No 13 Tahun 2003 tentang Ketenagakerjaan.

Pasal 155

(1) Pemutusan hubungan kerja tanpa penetapan sebagaimana dimaksud dalam Pasal 151 ayat (3) batal demi hukum.

(2) Selama putusan lembaga penyelesaian perselisihan hubungan industrial belum ditetapkan, baik Pengusaha maupun Pekerja/Buruh harus tetap melaksanakan segala kewajibannya.

(3) Pengusaha dapat melakukan penyimpangan terhadap ketentuan sebagaimana dimaksud dalam ayat (2) berupa tindakan skorsing kepada Pekerja/Buruh yang sedang dalam proses pemutusan hubungan kerja dengan tetap wajib membayar upah beserta hak-hak lainnya yang biasa diterima Pekerja/Buruh.

Dalam uraian dibawah akan dijelaskan mengenai pasal-pasal dalam UU No 13 Tahun 2003 tentang Ketenagakerjaan yang berisi penyelesaian perselisihan lewat jalur bipartit, mediasi, konsiliasi dan arbitrase. Uraian dibawah juga akan dijelaskan mengenai pasal-pasal dalam Undang-Undang Nomor 2 Tahun 2004 tentang Penyelesaian Perselisihan Hubungan Industrial yang mengatur lama waktu penyelesaian lewat bipartit yaitu kurang lebih 1 (satu) bulan dan mediasi kurang lebih 1 (satu) bulan. Penyelesaian ditingkat pengadilan hubungan industrial dari mulai pengajuan gugatan, jawaban, replik, duplik, pembuktian, kesimpulan dan putusan menghabiskan waktu 50 (lima puluh) hari. Sementara bagi para pihak yang belum puas terhadap putusan yang dikeluarkan oleh Pengadilan Hubungan Industrial dapat mengajukan upaya kasasi ke Mahkamah Agung. Proses di Mahkamah Agung sampai dikeluarkannya putusan kurang lebih memakan waktu 30 (tiga puluh) hari. Jika ditotal secara keseluruhan sampai dikeluarkannya putusan pada tingkat kasasi, waktu yang diperlukan kurang lebih 140 hari atau kurang lebih 5 (lima) bulan.

Namun pada prakteknya dilapangan jarang ditemukan penyelesaian perselisihan pemutusan hubungan kerja mulai dari tingkat bipartit sampai dengan putusan pada tingkat kasasi selesai dalam waktu 140 hari sebagaimana diamanatkan dalam Pasal 3, 15, 103 dan 115 Undang-Undang No 2 Tahun 2004 tentang Penyelesaian Perselisihan Hubungan Industrial.

Adapun penyebab tidak selesainya penyelesaian perselisihan tersebut dalam waktu 140 hari seperti yang diamanatkan oleh UU No 2 Tahun 2004 tentang Penyelesaian Perselisihan Hubungan Industrial adalah dikarenakan adanya alasan teknis dari Pekerja/Buruh, Pengusaha maupun dari para Hakim yang mengadili perkara pada tingkat pertama hingga kasasi. 
Untuk itu apabila penyelesaian perselisihan pemutusan hubungan kerja tersebut tidak tepat waktu atau melebihi 140 hari, maka penyelesaiannya mengacu kepada Pasal 155 ayat 2 UU No 13 Tahun 2003 tentang Ketenagakerjaan juncto putusan Mahkamah Konstitusi No 37/PUU-IX/2011, yaitu selama belum mendapatkan putusan yang berkekuatan hukum tetap (inkracht van gewijsde), maka Pekerja/Buruh harus mendapatkan hak-hak yang seharusnya dia dapatkan biasanya, seperti upah.

\section{Penyelesaian Perselisihan Hubungan Industrial Melalui Bipartit}

Penyelesaian perselisihan hubungan industrial dapat dilakukan dengan berbagai cara seperti penyelesaian secara bipartit. Penyelesaian perselisihan melalui bipartit diselesaikan paling 30 (tiga puluh) hari kerja sejak tanggal dimulainya perundingan (Pasal 3 ayat 2 UU No 2 Tahun 2004 tentang Penyelesaian Perselisihan Industrial). Apabila dalam jangka waktu 30 (tiga puluh) hari tersebut, salah satu pihak menolak untuk berunding atau telah dilakukan perundingan tetapi tidak mencapai kesepakatan, maka perundingan bipartit dianggap gagal (Pasal 3 ayat 3 UU No 2 Tahun 2004 tentang Penyelesaian Perselisihan Hubungan Industrial).

Tenggang waktu dalam penyelesaian secara bipartit dilakukan dalam jangka waktu 30 (tiga puluh) hari tanpa adanya perpanjangan jangka waktu, sehingga apabila telah lewat jangka waktu dan belum ada kesepakatan, maka penyelesaian secara bipartit tersebut dianggap gagal. Pada penyelesaian secara bipartit, apabila perundingan mencapai kesepakatan, wajib dibuat perjanjian bersama yang berisikan hasil perundingan. Sebaliknya, jika tidak tercapai kesepakatan, harus dibuat risalah perundingan sebagai bukti telah dilakukan perundingan bipartit."

Perjanjian bersama yang menjadi bukti telah tercapainya kesepakatan harus ditandatangani oleh para pihak. Perjanjian bersama tersebut mengikat dan menjadi hukum serta wajib dilaksanakan oleh para pihak. Selanjutnya, perjanjian bersama tersebut wajib didaftarkan oleh para pihak yang melakukan perjanjian pada Pengadilan Hubungan Industrial pada Pengadilan Negeri di wilayah para pihak mengadakan perjanjian bersama (Pasal 7 ayat 4 UU No 2 Tahun 2004 tentang Penyelesaian Perselisihan Hubungan Industrial).

Jika perundingan bipartit gagal, maka salah satu atau kedua belah pihak mencatatakan perselisihannya kepada instansi yang bertanggungjawab di bidang ketenagakerjaan (Dinas Tenaga Kerja setempat) dengan melampirkan bukti bahwa upaya-upaya penyelesaian melalui perundingan bipartit telah dilakukan, berupa risalah perundingan.

\section{Penyelesaian Perselisihan Hubungan Industrial Melalui Mediasi (Tripartit)}

Cara penyelesaian perselisihan hubungan industrial yang selanjutnya adalah secara tripartit atau mediasi. Jika perundingan secara bipartit tidak mencapai kesepakatan,

\footnotetext{
${ }^{8}$ Adrian Sutedi, Hukum Perburuhan, Jakarta: Sinar Grafika, 2011, hal 108
} 
maka dapat dilakukan perundingan atau mediasi hubungan industrial (selanjutnya disebut mediasi) antara pekerja dan Pengusaha dengan melibatkan unsur dari Pemerintah, yaitu Dinas Tenaga Kerja (perundingan tripartit).

Mediasi merupakan salah satu bentuk alternatif penyelesaian sengketa dalam ketentuan Undang-Undang Republik Indonesia Nomor 30 Tahun 1999 tentang Arbitrase dan Alternatif Penyelesaian Sengketa. Secara etimologi, istilah mediasi berasal dari bahasa Latin, mediare yang berarti berada di tengah. Makna ini menunjuk pada peran yang ditampilkan pihak ketiga sebagai mediator dalam menjalankan tugasnya menengahi dan menyelesaikan sengketa antara para pihak. Berada di tengah juga bermakna mediator harus berada pada posisi netral dan tidak memihak dalam menyelesaikan sengketa. ${ }^{9}$

Menurut penjelasan dalam Kamus Besar Bahasa Indonesia (KBBI), kata mediasi diberi arti sebagai proses pengikutsertaan pihak ketiga dalam penyelesaian suatu perselisihan sebagai penasihat. ${ }^{10}$ Penjelasan mediasi dari sisi kebahasaan (etimologi) lebih menekankan pada keberadaan pihak yang menjembatani para pihak yang bersengketa untuk menyelesaikan perselisihannya. ${ }^{11}$

Syarat pihak ketiga yang diikutsertakan dalam proses mediasi adalah bersifat netral atau tidak memihak. Syarat ini dianggap meliputi sikap independen sehingga pengertiannya mencakup: ${ }^{12}$

a. Bersikap bebas dan merdeka dari pengaruh siapapun

b. Bebas secara mutlak dari paksaan dan direktiva pihak manapun

Sedang syarat tidak memihak mengandung arti sebagai berikut:

a. Harus benar-benar bersifat imparsialitas, tidak boleh kepada salah satu pihak, dan

b. Tidak boleh bersikap diskriminatif, tetapi harus memberi perlakuan yang sama (equal treatment) kepada para pihak

Mediator dalam penyelesaian perselisihan hubungan industrial secara mediasi adalah pegawai dari instansi pemerintah yang bertanggung jawab dibidang ketenagakerjaan, yaitu Dinas Tenaga Kerja. Dinas Tenaga Kerja akan menunjuk seorang mediator yang akan menjadi penengah antara pekerja dengan Pengusaha.

Adanya mediasi dengan mediator dari Dinas Tenaga Kerja merupakan prasyarat sebelum perselisihan hubungan industrial masuk ke pengadilan, sehingga mediasi

\footnotetext{
${ }^{9}$ Syahrizal Abbas, Mediasi Dalam Perspektif Hukum Syariah, Hukum Adat Dan Hukum Nasional, Jakarta: Kencana, 2009, hal 2

${ }^{10} \mathrm{Ibid}$, hal 3

${ }^{11}$ Ibid

${ }^{12}$ M. Yahya Harahap, Pembahasan Permasalahan Dan Penerapan KUHAP, Jakarta: Sinar Grafika, hal 77
} 
tidak perlu dilakukan lagi dipengadilan, melainkan dilakukan di Dinas Tenaga Kerja. Hal ini bertujuan untuk menghindari adanya penumpukan perkara dipengadilan.

Dalam hal tercapai kesepakatan penyelesaian perselisihan hubungan industrial melalui mediasi, maka dibuat Perjanjian Bersama yang ditandatangani oleh para pihak dan disaksikan oleh Mediator serta didaftar di Pengadilan Hubungan Industrial untuk mendapatkan akta bukti pendaftaran.

\section{Penyelesaian Perselisihan Hubungan Industrial Melalui Konsiliasi}

Upaya yang dapat dilakukan dalam penyelesaian perselisihan hubungan selain dengan jalur mediasi dengan pemerintah adalah dengan jalur konsiliasi hubungan industrial (selanjutnya disebut konsiliasi). Menurut Pasal 1 ayat 13 Undang-Undang No 2 Tahun 2004 tentang Penyelesaian Perselisihan Hubungan Industrial, konsiliasi adalah penyelesaian perselisihan kepentingan, perselisihan pemutusan hubungan kerja atau perselisihan antar serikat Pekerja/Buruh hanya dalam satu perusahaan melalui musyawarah yang ditengahi oleh seorang atau lebih konsiliator yang netral.

Penyelesaian oleh konsiliator dilaksanakan setelah pihak mengajukan permintaan penyelesaian secara tertulis kepada konsiliator yang ditunjuk dan disepakati oleh para pihak. ${ }^{13}$ Para pihak dapat mengetahui nama konsiliator yang akan dipilih dan disepakati dari daftar nama konsiliator yang dipasang dan diumumkan pada kantor instansi Pemerintah yang bertanggung jawab dibidang ketenagakerjaan setempat. ${ }^{14}$

Menurut Pasal 24 UU No 2 Tahun 2004 tentang Penyelesaian Perselisihan Hubungan Industrial, dalam hal anjuran tertulis tersebut ditolak oleh salah satu pihak atau kedua belah pihak yang berselisih, maka salah satu pihak atau para pihak yang berselisih dapat melanjutkan penyelesaian perselisihan dengan pengajuan gugatan ke Pengadilan Hubungan Industrial pada Pengadilan Negeri setempat.

\section{Penyelesaian Perselisihan Hubungan Industrial Melalui Arbitrase}

Penyelesaian hubungan industrial yang selanjutnya adalah melalui arbitrase yang diatur dalam Undang-Undang Nomor 2 Tahun 2004 tentang Penyelesaian Perselisihan Hubungan Industrial dalam bagian IV Pasal 29 sampai dengan Pasal 54. Para pihak yang berperkara tidak harus memilih jalur mediasi ataupun konsiliasi. Adakalanya para pihak lebih percaya kepada arbiter yang ditunjuk karena penyelesaian perkara lewat jalur mediasi ataupun konsiliasi dianggap sangat panjang dan rumit. Walaupun dalam kenyataan dilapangan, Peneliti menemukan sangat sedikit yang menempuh jalur arbitrase.

\footnotetext{
${ }^{13}$ Pasal 18 ayat 2 UU No 2 Tahun 2004 tentang Penyelesaian Perselisihan Hubungan Industrial

${ }^{14}$ Pasal 18 ayat 3 UU No 2 Tahun 2004 tentang Penyelesaian Perselisihan Hubungan Industrial
} 
Terkait dengan masalah upah proses (upah dalam tenggang waktu menunggu putusan pengadilan) dalam prakteknya di Pengadilan terdapat tiga macam putusan Pengadilan Hubungan Industrial (PHI) yakni :

1. Putusan Hakim menghukum Pengusaha membayar upah proses selama enam bulan atau membayar sampai putusan berkekuatan hukum tetap (inkracht van gewijsde). Putusan ini didasarkan pada Pasal 16 Kepmenaker No 150 Tahun 2000 dan Pasal 155 ayat 2 UU No 13 Tahun 2003 tentang Ketenagakerjaan juncto Putusan MK No 37 /PUU-IX/2011.

2. Putusan Hakim menghukum Pengusaha untuk tidak membayar upah proses. Putusan ini murni didasarkan pada diskresi atau kewenangan yang dimiliki Hakim dalam memeriksa dan memutus suatu perkara.

\section{Putusan Hakim Terhadap Pemberian Upah Proses Selama 6 Bulan Atau Lebih}

Putusan Hakim terhadap pemberian upah proses selama 6 bulan atau lebih dapat dilihat dalam Putusan Hakim Mahkamah Agung Nomor 70 K/Pdt.Sus/2013 yang melibatkan antara PT Resati Putra Indah melawan Elti Aryani, dimana dalam putusan tersebut menolak permohonan kasasi PT. Resati Putra Indah dan memerintahkan agar PT Resati Putra Indah membayar upah proses selama 10 bulan.

Dalam putusan tingkat pertama, Hakim memerintahkan Tergugat/Pengusaha untuk membayar hak-hak Penggugat/Pekerja yang salah satunya adalah membayar upah proses selama perselisihan sejak bulan Juli 2013 sampai dengan Februari 2014 yaitu sebesar 8 (delapan) bulan upah.

Kemudian, Tergugat/Pengusaha keberatan dengan putusan tersebut dan mengajukan kasasi ke Mahkamah Agung. Dalam putusan Hakim Mahkamah Agung, Hakim menghukum Tergugat/Pengusaha untuk membayar upah proses selama 6 (enam) bulan upah.

Dalam pertimbangannya, Hakim Mahkamah Agung berpendapat bahwa Penggugat/Pekerja berhak atas upah proses berdasarkan ketentuan Pasal 93 ayat 2 huruf f jo Pasal 155 ayat 2 UU No 13 Tahun 2003 tentang Ketenagakerjaan. Namun, penetapan besarnya upah proses tersebut harus memperhatikan rasa keadilan sebagaimana dimaksud dalam ketentuan Pasal 100 UU Nomor 13 Tahun 2003 jo Pasal 5 UU Nomor 48 Tahun 2009 tentang Kekuasaan Kehakiman. Pada kenyataannya, tidak bekerjanya Penggugat/Pekerja, sementara disisi yang lain Pengusaha tetap memberikan kewajiban kepada pihak Tergugat akan membebani Pengusaha itu sendiri. Pertimbangan hukum selanjutnya dari Hakim Mahkamah Agung adalah yurisprudensi yang telah ada tentang besarnya upah proses yang ditetapkan sebesar 6 bulan upah, sehingga Hakim menetapkan pembayaran upah proses sebesar 6 bulan upah dalam kasus tersebut.

Dalam Surat Edaran Mahkamah Agung No 3 Tahun 2015 tentang Pemberlakuan Rumusan Hasil Rapat Pleno Kamar Mahkamah Agung Tahun 2015 Sebagai 
Pedoman Pelaksanaan Tugas Bagi Pengadilan, dalam bagian perdata khusus huruf $\mathrm{f}$ diatur bahwa, pasca Putusan MK Nomor 37/PUU-IX/2011 terkait dengan upah proses, maka isi amar putusan dalam perkara pemutusan hubungan kerja yang menimbulkan upah proses adalah menghukum Pengusaha membayar upah proses selama 6 bulan. Kelebihan waktu dalam proses penyelesaian hubungan industrial sebagaimana dimaksud dalam UU No 2 Tahun 2004 tentang Penyelesaian Perselisihan Hubungan Industrial bukan lagi tanggung jawab para pihak. Hal ini didukung juga oleh Pasal 16 Kepmenaker No 150 Tahun 2000 dimana sampai saat ini Kepmenaker tersebut belum dicabut. Dalam Pasal 16 Kepmenaker No 150 Tahun 2000 disebutkan bahwa sebelum ijin pemutusan hubungan kerja dikeluarkan maka pihak Pengusaha dapat menskorsing Pekerja/Buruh paling lama 6 (enam) bulan dengan tetap membayar upahnya selama 6 (enam) bulan. Asumsi bahwa putusan Hakim yang mempunyai kekuatan hukum tetap (inkracht van gewijsde) sudah dapat diperoleh dalam jangka waktu 6 (enam) bulan.

Selanjutnya, terdapat juga putusan Hakim yang menghukum tergugat untuk membayar upah proses sebesar 10 bulan upah (lebih dari 6 bulan) merupakan putusan yang didasarkan kepada Pasal 155 ayat 2 UU No 13 Tahun 2003 tentang Ketenagakerjaan. Dalam pasal tersebut dinyatakan bahwa upah proses dibayarkan sampai dengan adanya putusan Hakim yang berkekuatan hukum tetap. Hal tersebut juga dikuatkan oleh Putusan MK No 37 Tahun 2011.

Dalam hal ini, Hakim berani menyingkirkan ketentuan yang terdapat dalam Kepmenaker No 150 Tahun 2000 dan juga Surat Edaran Mahkamah Agung RI No 3 Tahun 2015 tentang Pemberlakuan Rumusan Hasil Rapat Pleno Kamar Mahkamah Agung Tahun 2015 Sebagai Pedoman Pelaksanaan Tugas Bagi Pengadilan. Dalam Kepmenaker dan Surat Edaran tersebut dinyatakan bahwa upah proses yang dibayarkan kepada pekerja dalam proses menunggu putusan pengadilan ditetapkan sebanyak 6 (enam) bulan upah.

Dalam kasus tersebut, Hakim mengenyampingkan ketentuan yang terdapat dalam Kepmenaker No 150 Tahun 2000. Hal tersebut dilakukan setelah Hakim menguji dan mengkaji bahwa ketentuan pasal tersebut bertentangan dengan ketertiban, kepentingan dan kemaslahatan umum, maka dalam keadaan seperti ini Hakim dapat mengenyampingkan pasal tersebut.

\section{Putusan Hakim Yang Tidak Memberikan Upah Proses}

Perihal pemberian upah proses, terdapat juga putusan Hakim Mahkamah Agung dalam perkara lain yang tidak memberikan upah proses kepada penggugat. Hal tersebut terlihat dalam Putusan Nomor 04/Pdt.Sus-PHI/2014/PN.Pbr. Perkara tersebut melibatkan antara CV Pajero Motor dengan Hansen Sinaga yang merupakan karyawan CV Pajero Motor.

Perselisihan hubungan industrial yang terjadi antara Penggugat/Pekerja dengan Tergugat/Pengusaha bermula dari adanya masalah pribadi antara penggugat dengan 
beberapa karyawan tergugat yang kemudian berujung dengan adanya pemutusan hubungan kerja terhadap Penggugat/Pekerja.

Tergugat/Pengusaha juga melakukan demosi (penurunan jabatan) kepada Penggugat/Pekerja menjadi collector. Tergugat/Pengusaha juga melakukan mutasi dengan adanya surat mutasi yang dikeluarkan oleh Tergugat/Pengusaha pada tanggal 01 Juni 2013 kepada Penggugat/Pekerja yang dimutasi ke CV Duta Motor Cabang Binjai sebagai collector. Akan tetapi, Penggugat/Pekerja tidak menjalankan mutasi tersebut dan tidak menjalankan tugasnya ditempat yang baru.Tergugat/Pengusaha juga tidak pernah melakukan pemanggilan terhadap Penggugat/Pekerja, baik diperusahaan lama maupun perusahaan baru. Oleh karena itu, Hakim berpendapat Penggugat dan Tergugat sudah tidak melaksanakan hak dan kewajibannya dan dapat disimpulkan bahwa Penggugat/Pekerja sudah tidak berkeinginan lagi untuk bekerja dan Tergugat/Pengusaha juga sudah tidak berkeinginan melanjutkan hubungan kerja dengan Penggugat/Pekerja dan oleh karena itu relevan pemutusan hubungan kerja terjadi antara Penggugat dengan Tergugat sejak dikeluarkan surat mutasi tersebut yakni sejak tanggal 1 Juni 2013.

Perkara dilanjutkan dengan mediasi oleh Dinas Tenaga Kerja dan tidak tercapai kesepakatan diantara kedua belah pihak. Perkara dilanjutkan ke Pengadilan Hubungan Industrial pada Pengadilan Negeri Pekanbaru. Dalam amar putusannya, Hakim menyatakan bahwa upah proses yang menjadi tuntutan penggugat ditolak karena pemutusan hubungan kerja ditetapkan sejak 1 Juni 2013 dan penggugat menerima upah terakhir bulan Mei 2013

Hakim memandang pemutusan hubungan kerja terjadi saat dikeluarkannya surat mutasi tanggal 01 Juni 2013 kepada Penggugat. Dalam pelaksanaannya, Penggugat tidak melaksanakan kewajibannya ditempat yang baru sesuai dengan surat mutasi tersebut. Tergugat juga tidak melakukan pemanggilan kepada Penggugat perihal tindakan Penggugat yang tidak melaksanakan kewajiban pekerjaannya ditempat yang baru. Dengan demikian, putus hubungan kerja antara Penggugat dan Tergugat sejak dikeluarkannya surat mutasi tersebut karena masing-masing pihak tidak melaksanakan kewajibannya setelah dikeluarkannya surat mutasi tersebut.

Selanjutnya, perkara dilanjutkan ke Mahkamah Agung. Putusan Hakim Mahkamah Agung menolak permohonan kasasi dari CV Pajero Motor. Mahkamah Agung menguatkan putusan Hakim Pengadilan Hubungan Industrial pada Pengadilan Negeri Pekanbaru, termasuk didalam amar putusannya yang menyatakan tuntutan upah proses yang diajukan oleh penggugat ditolak.

Hakim memandang bahwa upah proses dalam pemutusan hubungan kerja tidak menghitung waktu dalam proses berperkara atau waktu dalam proses menunggu putusan lembaga penyelesaian perselisihan hubungan industrial. Dalam hal hal ini, Hakim tidak memperhatikan ketentuan yang terdapat dalam Pasal 155 ayat 2 UU Ketenagakerjaan yang menyatakan bahwa, "Selama putusan lembaga penyelesaian 
perselisihan hubungan industrial belum ditetapkan, baik Pengusaha maupun Pekerja/Buruh harus tetap melaksanakan segala kewajibannya."

Dalam hal menunggu penetapan dari Pengadilan, Pasal 155 ayat 2 UU Ketenagakerjaan ini mengandung pengertian bahwa sebelum adanya putusan pengadilan yang memperoleh kekuatan hukum tetap tentang penetapan Pemutusan Hubungan Kerja, maka buruh tetap menyelesaikan kewajibannya seperti biasa yakni bekerja dan menerima gaji, begitu juga Pengusaha wajib menyelesaikan kewajibannya seperti biasa pula yakni memberi gaji pada buruh dan menjalankan roda usahanya seperti biasa.

Hakim dapat menciptakan hukum baru atau mempertahankan yurisprudensi yang sudah bersifat stare decesis. Terkait dengan putusan-putusan pengadilan, terminologi stare decisis mengungkapkan bahwa putusan pengadilan saat ini untuk kasus yang sama harus memutuskan sama seperti yang pernah diputus di masa lalu. Apabila Hakim akan menyimpang dari putusan Hakim sebelumnya terhadap kasus yang sama, maka hal itu dapat dilakukan dengan menyebutkan alasan yang jelas dan logis. Terminologi ini terkait juga dengan prinsip kebebasan Hakim dalam memeriksa dan memutus suatu perkara.

Adanya ketidakselarasan putusan Hakim dalam menjatuhkan putusan terkait pemberian upah proses menunjukkan perbedaan paradigma Hakim dalam menjatuhkan putusan. Dalam pelaksanaannya, Hakim dapat mengikuti putusan Hakim yang terdahulu terhadap perkara yang sama (yurisprudensi). Tetapi disatu sisi, Hakim dapat menyimpang dari putusan Hakim sebelumnya terhadap kasus yang sama. Hal tersebut dapat dilakukan dengan menyebutkan alasan yang jelas dan logis. Teori ini terkait juga dengan prinsip kebebasan Hakim dalam memeriksa dan memutus suatu perkara.

Adanya ketidakselarasan Hakim dalam menjatuhkan putusan terkait dengan upah proses juga disebabkan karena adanya tumpang tindah aturan. Dalam Pasal 155 ayat 2 UU No 13 Tahun 2003 tentang Ketenagakerjaan diatur bahwa, "Selama putusan lembaga penyelesaian perselisihan hubungan industrial belum ditetapkan, baik Pengusaha maupun Pekerja/Buruh harus tetap melaksanakan segala kewajibannya". Pasal tersebut mengandung arti bahwa selama menunggu putusan dari lembaga penyelesaian perselisihan hubungan industrial, Pengusaha tetap mempekerjakan pekerja, begitu juga dengan pekerja berhak untuk menerima upah.

Hal diatas diperkuat dengan adanya Putusan MK No 37 /PUU-IX/2011. Putusan tersebut menyatakan dasar acuan tentang pemberian upah proses adalah Pasal 155 ayat (2) UU No 13 tahun 2003 tentang Ketenagakerjaan, yakni upah proses harus dibayarkan Pengusaha hingga perkara memperoleh kekuatan hukum tetap.

Disatu sisi, terdapat Kepmenaker No 150 Tahun 2000 tentang Penyelesaian Pemutusan Hubungan Kerja Dan Penetapan Uang Pesangon, Uang Penghargaan Masa Kerja Dan Ganti Kerugian Di Perusahaan. Dalam Pasal 16 Kepmenaker tersebut dinyatakan bahwa selama menunggu putusan dari lembaga penyelesaian 
perselisihan hubungan industrial terkait dengan pemutusan hubungan kerja, Pengusaha dapat melakukan skorsing kepada pekerja dengan membayar upah proses paling lama 6 (enam) bulan.

Dalam perkara tersebut, Hakim berani berperan untuk melakukan contra legem, yaitu tindakan Hakim yang dalam putusannya melanggar hal yang ditentukan dalam pasal undang-undang tertentu dengan cara menyingkirkan penerapan Pasal 155 ayat 2 UU No 13 Tahun 2003 tentang Ketenagakerjaan.

\section{Pertimbangan Atau Pendekatan Hakim (Teori) Dalam Memberikan Putusan Terhadap Upah Proses}

Putusan Hakim dalam pengadilan berdasarkan fungsinya dalam mengakhiri perkara dapat dibagi sebagai berikut :

a. Putusan Akhir

Putusan akhir adalah putusan yang mengakhiri pemeriksaan di persidangan baik telah melalui semua tahapan pemeriksaan yang tidak/belum menempuh semua tahapan pemeriksaan.

b. Putusan Sela

Putusan sela adalah putusan yang dijatuhkan masih dalam proses pemeriksaan perkara tujuan untuk memperlancar jalannya pemeriksaan. Putusan tidak mengakhiri pemeriksaan, tetapi akan berpengaruh terhadap arah dan jalannya pemeriksaan.

Apabila dilihat dari isinya terhadap gugatan/perkara, putusan Hakim dibagi sebagai berikut : ${ }^{15}$

a. Putusan tidak menerima

Putusan tidak menerima adalah putusan yang menyatakan bahwa Hakim tidak menerima gugatan penggugat/permohonan pemohon atau dengan kata lain penggugat/permohonan dari pemohon tidak diterima karena gugatan/permohonan tidak memenuhi syarat hukum baik secara formail maupun materiil.

b. Putusan menolak gugatan penggugat

Putusan menolak gugatan penggugat adalah putusan akhir yang dijatuhkan setelah menempuh semua tahapan pemeriksaan di mana ternyata dalil-dalil gugatan tidak terbukti.

c. Putusan mengabulkan gugatan penggugat untuk sebagian dan menolak/tidak menerima selebihnya

Putusan ini merupakan putusan akhir dan dalam suatu perkara, dalil gugatan ada yang terbukti dan ada yang tidak terbukti atau tidak memenuhi syarat sehingga dalil gugatan yang terbukti maka tuntutannya dikabulkan.

d. Putusan mengabulkan gugatan penggugat untuk seluruhnya

${ }^{15}$ M. Yahya Harahap, Op.cit, hal 77

JOURNAL OF LAW AND POLICY TRANSFORMATION 
Putusan ini dijatuhkan apabila syarat-syarat gugatan telah terpenuhi dan seluruh dalil-dalil dari tergugat yang mendukung petitum ternyata terbukti. Untuk mengabulkan suatu petitum harus didukung dalil gugatan. ${ }^{16}$

Kekuasaan kehakiman merupakan lembaga yang mandiri dan bebas dari segala bentuk campur tangan dari luar. Hal tersebut diatur dalam Pasal 1 ayat 1 UndangUndang No 48 Tahun 2009 tentang Kekuasaan KeHakiman. Kekuasaan Kehakiman merupakan kekuasaan negara yang merdeka untuk menyelenggarakan peradilan guna menegakkan hukum dan keadilan berdasarkan Pancasila dan Undang-Undang Dasar Negara Republik Indonesia Tahun 1945. Oleh karena itu, Hakim sebagai unsur inti dalam sumber daya manusia yang menjalankan kekuasaan kehakiman di Indonesia dalam menjalankan tugas pokok dan fungsi kekuasaan kehakiman wajib menjaga kemandirian peradilan melalui integritas kebebasan Hakim dalam memeriksa dan memutus perkara. ${ }^{17}$

Dalam diri Hakim diemban suatu amanah agar peraturan perundang-undangan diterapkan secara benar dan adil, dan apabila penerapan peraturan perundangundangan akan menimbulkan ketidakadilan, maka Hakim wajib berpihak pada keadilan (moral justice) dan mengenyampingan hukum dan peraturan perundangundangan (legal justice). Walaupun definisi dari adil itu sangat susah untuk ditafsirkan. Tetapi Peneliti dalam menafsirkan pengertian adil tersebut mengambil pendapat dari beberapa ahli seperti Hans Kelsen dan Kahar Mahsyur.

Menurut Hans Kelsen, keadilan adalah suatu kualitas yang berhubungan tidak dengan isi dari perintah positif, tetapi pada pelaksanaannya. Keadilan berarti menjaga berlangsungnya perintah positif dengan menjalankannya secara bersungguh-sungguh. ${ }^{18}$ Dengan kata lain bahwa para pihak yang berselisih harus mematuhi dan melaksanakan putusan yang diambil oleh Hakim karena putusan yang dibacakan Hakim itulah keadilan bagi kedua belah pihak.

Menurut Kahar Masyhur dalam bukunya mengemukakan pendapat-pendapat tentang apakah yang dinamakan adil, terdapat tiga hal tentang pengertian adil, yaitu : ${ }^{19}$

1. Adil ialah meletakan sesuatu pada tempatnya.

2. Adil ialah menerima hak tanpa lebih dan memberikan orang lain tanpa kurang.

3. Adil ialah memberikan hak setiap yang berhak secara lengkap tanpa lebih tanpa kurang antara sesama yang berhak dalam keadaan yang sama, dan penghukuman orang jahat atau yang melanggar hukum, sesuai dengan kesalahan dan pelanggaran.

Upah proses merupakan upah yang diberikan kepada pekerja dalam masa tenggang waktu menunggu putusan pengadilan sehubungan dengan perselisihan

\footnotetext{
${ }^{16} \mathrm{Ibid}$, hal 82

${ }^{17}$ Ahmad Kamil, Filsafat Kebebasan Hakim, Jakarta: Kencana Prenada Pratama, 2012, hal 305

${ }^{18}$ Djohansjah J, Reformasi Mahkamah Agung Menuju Independensi Kekuasaan KeHakiman, Jakarta, Kesaint Blanc, 2008, hlm 56

${ }^{19}$ Kahar Masyhur, Membina Moral Dan Akhlak, Jakarta: Kalam Mulia, 1985, hal 71
} 
hubungan industrial yang dialaminya. Dalam prakteknya, terdapat putusan pengadilan yang berbeda-beda perihal pemberian upah proses yaitu sebagai berikut :

1. Putusan Hakim menghukum Pengusaha membayar upah proses enam bulan atau lebih

2. Putusan Hakim yang menghukum Pengusaha tidak membayar upah proses Ditemukan fakta-fakta menarik mengenai besarnya upah proses yang diputus oleh Majelis Hakim Agung. Fakta-fakta tersebut adalah sebagai berikut:

1. Majelis Hakim Agung dalam putusannya menetapkan besarnya upah proses hanya sebesar enam bulan atau lebih

2. Majelis Hakim Agung dalam putusannya tidak memberikan upah proses

Dalam Pasal 16 ayat 1 Kepmenakertrans No 150 Tahun 2000 diatur bahwa, selama proses pemutusan hubungan kerja, Pengusaha dapat melakukan skorsing kepada pekerja sesuai dengan ketentuan dalam perjanjian kerja atau peraturan perusahaan atau kesepakatan kerja bersama, dengan tetap membayar upah dan hak-hak yang biasa diterima oleh pekerja. Dalam Pasal 16 ayat 3 Kepmanakertrans No 150 Tahun 2000 diatur juga bahwa pemberian upah selama skorsing paling lama adalah 6 (enam) bulan.

Dalam Surat Edaran Mahkamah Agung RI No 3 Tahun 2015 tentang Pemberlakuan Rumusan Hasil Rapat Pleno Kamar Mahkamah Agung Tahun 2015 Sebagai Pedoman Pelaksanaan Tugas Bagi Pengadilan dinyatakan juga bahwa, "Pasca Putusan MK Nomor 37/PUU-IX/2011, tertanggal 19 September 2011 terkait dengan upah proses, maka isi amar putusan adalah menghukum Pengusaha membayar upah proses selama 6 bulan. Kelebihan waktu dalam proses PHI sebagaimana dimaksud dalam UndangUndang Nomor 2 Tahun 2004 tentang Penyelesaian Perselisihan Hubungan Industrial bukan lagi menjadi tanggung jawab para pihak."

Berdasarkan Surat Edaran Mahkamah Agung tersebut, Mahkamah Agung memandang bahwa upah proses yang adil adalah sebesar 6 (enam) bulan upah karena jika mengacu kepada prosedur penyelesaian perselisihan hubungan industrial berdasarkan kepada Undang-Undang Nomor 2 Tahun 2004 tentang Penyelesaian Perselisihan Hubungan Industrial, maka jangka waktu penyelesaian perselisihan mulai dari perundingan bipartit sampai dengan keluarnya putusan pengadilan hubungan industrial adalah 6 (enam) bulan.

Pada dasarnya, surat edaran dikeluarkan hanya sekadar menjelaskan atau memuat petunjuk teknis suatu peraturan umum. Dalam Surat Keputusan Mahkamah Agung Republik Indonesia Nomor 271/KMA/SK/X/2013 tentang Pedoman Penyusunan Kebijakan Mahkamah Agung Republik Indonesia menyebutkan pengertian surat edaran sebagai berikut: Surat Edaran Mahakamah Agung adalah bentuk edaran pimpinan Mahkamah Agung ke seluruh jajaran peradilan yang berisi bimbingan 
dalam penyelenggaraan peradilan, yang lebih bersifat administrasi dan juga memuat pemberitahuan tentang hal tertentu yang dianggap penting dan mendesak. ${ }^{20}$

Surat Edaran Mahkamah Agung (SEMA) dibentuk berdasarkan ketentuan Pasal 12 ayat (3) Undang-undang No. 1 tahun 1950 tentang Susunan, Kekuasaan dan Jalan Pengadilan Mahkamah Agung Indonesia. Mahkamah Agung merupakan lembaga peradilan yang berwenang melakukan pengawasan terhadap lembaga peradilan di bawahnya. Guna kepentingan jawatan maka itu Mahkamah Agung berhak memberi peringatan-peringatan, teguran dan petunjuk petunjuk yang dipandang perlu dan berguna kepada pengadilan-pengadilan dan para Hakim tersebut, baik dengan surat tersendiri maupun dengan surat edaran.

Landasan hukum kekuasaan dan kewenangan Mahkamah Agung menerbitkan Surat Edaran diatur dalam Pasal 32 ayat (4) Undang-Undang Mahkamah Agung yang menyatakan bahwa, Mahkamah Agung berwenang memberi petunjuk, teguran, atau peringatan yang dipandang perlu kepada pengadilan di semua lingkungan peradilan." Jika mengacu kepada proses penyelesaian perselisihan hubungan industrial melalui jalur bipartit, menurut Pasal 3 ayat 2 UU No 2 Tahun 2004 tentang Penyelesaian Perselisihan Hubungan Industrial, penyelesaian perselisihan secara bipartit harus diselesaikan paling lama 30 (tiga puluh) hari kerja sejak tanggal dimulainya perundingan.

UU No 2 Tahun 2004 tentang Penyelesaian Perselisihan Hubungan Industrial mensyaratkan penyelesaian perselisihan hubungan industrial melalui jalur bipartit harus diselesaikan dalam jangka waktu 30 (tiga puluh) hari sejak dimulainya perundingan. Namun, dalam prakteknya, penyelesaian perselisihan hubungan industrial melalui jalur bipartit sering kali lebih dari 30 (tiga puluh) hari sejak dimulainya perundingan. Sedangkan, dalam UU tersebut tidak diatur mekanisme perpanjangan jangka waktu penyelesaian perselisihan hubungan industrial melalui jalur bipartit jika melewati 30 (tiga puluh) hari.

Selanjutnya, jika penyelesaian perselisihan hubungan industrial berlanjut kepada tingkat mediasi, menurut Pasal 15 UU No 2 Tahun 2004 tentang Penyelesaian Perselisihan Hubungan Industrial diatur bahwa, penyelesaian perselisihan hubungan industrial melalui jalur tripartit harus diselesaikan dalam jangka waktu 30 (tiga puluh) hari. Dalam hal ini, mediator harus menyelesaian tugasnya dalam waktu selambatlambatnya 30 (tiga puluh) hari kerja terhitung sejak menerima pelimpahan penyelesaian perselisihan.

Ketentuan batas waktu penyelesaian perselisihan hubungan industrial melalui jalur tripartit juga sama dengan penyelesaian perselisihan hubungan industrial melalui jalur konsiliasi ataupun arbitrase. Dalam Pasal 25 ayat 2 UU No 2 Tahun 2004 tentang Penyelesaian Perselisihan Hubungan Industrial diatur bahwa, konsiliator

${ }^{20}$ Ibid, hal 59 
menyelesaikan tugasnya dalam waktu selambat-lambatnya 30 (tiga) puluh hari kerja terhitung sejak menerima permintaan penyelesaian perselisihan.

Dalam Pasal 40 ayat 1 UU No 2 Tahun 2004 tentang Penyelesaian Perselisihan Hubungan Industrial diatur bahwa, arbiter wajib menyelesaian perselisihan hubungan industrial dalam waktu selambat-lambatnya 30 (tiga puluh) hari kerja sejak penandatanganan surat perjanjian penunjukan arbiter. Dalam hal ini, jangka waktu penyelesaian perselisihan hubungan industrial melalui jalur triparit/konsiliasi/arbitrase dibatasi selama 30 (tiga) puluh hari kerja.

Dalam penyelesaian perselisihan hubungan industrial melalui pengadilan hubungan industrial, Pasal 103 UU No 2 Tahun 2004 tentang Penyelesaian Perselisihan Hubungan Industrial diatur bahwa, Majelis Hakim wajib memberikan putusan penyelesaian perselisihan hubungan industrial dalam waktu selambat-lambatnya 50 (lima puluh) hari kerja terhitung sejak sidang pertama. Dalam Pasal 106 UU No 2 Tahun 2004 tentang Penyelesaian Perselisihan Hubungan Industrial juga diatur bahwa, selambat-lambatnya 14 (empat belas) hari kerja sejak putusan ditandatangani, Panitera Muda harus sudah menerbitkan salinan putusan.

Jangka waktu penyelesaian perselisihan hubungan industrial (termasuk perselisihan pemutusan hubungan kerja) mulai dari bipartit sampai dengan putusan pengadilan hubungan industrial sesuai proses yang diatur dalam UU No 2 Tahun 2004 tentang Penyelesaian Perselisihan Hubungan Industrial, secara keseluruhan waktu penyelesaian memakan waktu sekitar lima setengah bulan sampai dengan enam bulan. Menurut pendapat Peneliti, jangka waktu pembayaran upah proses yang memenuhi unsur keadilan adalah 6 (enam) bulan atau lebih tergantung dari jangka waktu proses penyelesaian sampai diperoleh putusan yang mempunyai kekuatan hukum tetap (inkracht van gewijsde). Hal ini didasarkan kepada proses penyelesaian perselisihan hubungan industrial mulai dari bipartit sampai dengan putusan pengadilan hubungan indusrial (sesuai proses yang diatur dalam UU No 2 Tahun 2004 tentang Penyelesaian Perselisihan Hubungan Industrial) memakan waktu lima setengah bulan sampai 6 bulan dan apabila lebih dari 6 (enam) bulan, maka penentuan upah proses akan kembali mengacu kepada isi Pasal 155 ayat 2 UU No 13 Tahun 2003 tentang Ketenagakerjaan dan Putusan MK No 37 /PUU-IX/2011, yaitu upah proses diberikan sampai diperoleh putusan mempunyai kekuatan hukum tetap (inkracht van gewijsde).

Sebagai tambahan menurut Pasal 7 UU No 12 Tahun 2011 tentang Pembentukan Peraturan Perundang-Undangan disebutkan bahwa susunan hierarki peraturan perundang-undangan dimulai dari tingkat atas, yaitu sebagai berikut :

1. Undang-Undang Dasar 1945

2. Ketetapan Majelis Permusyawaratan Rakyat

3. Undang-Undang/Peraturan Pemerintah Pengganti Undang-Undang

4. Peraturan Pemerintah

5. Peraturan Presiden 
6. Peraturan Daerah Provinsi

7. Peraturan Daerah Kabupaten/Kota

Dalam Pasal 8 ayat 1 UU No 12 Tahun 2011 tentang Pembentukan Peraturan Perundan-Undangan dinyatakan bahwa, “

Jenis Peraturan Perundang-undangan selain sebagaimana dimaksud dalam Pasal 7 ayat (1) mencakup peraturan yang ditetapkan oleh Majelis Permusyawaratan Rakyat, Dewan Perwakilan Rakyat, Dewan Perwakilan Daerah, Mahkamah Agung, Mahkamah Konstitusi, Badan Pemeriksa Keuangan, Komisi Yudisial, Bank Indonesia, Menteri, badan, lembaga, atau komisi yang setingkat yang dibentuk dengan Undang-Undang atau Pemerintah atas perintah Undang-Undang, Dewan Perwakilan Rakyat Daerah Provinsi, Gubernur, Dewan Perwakilan Rakyat Daerah Kabupaten/Kota, Bupati/Walikota, Kepala Desa atau yang setingkat.

Dalam Pasal 8 ayat 2 UU No 12 Tahun 2011 tentang Pembentukan Peraturan PerundangUndangan juga dinyatakan bahwa :

Peraturan Perundang-undangan sebagaimana dimaksud pada ayat (1) diakui keberadaannya dan mempunyai kekuatan hukum mengikat sepanjang diperintahkan oleh Peraturan Perundang-undangan yang lebih tinggi atau dibentuk berdasarkan kewenangan.

Dari aturan tersebut, tidak dijelaskan posisi ataupun kedudukan dari Kepmenaker No 150 Tahun 2000, akan tetapi Kepmenaker tersebut tetap berlaku jika diperintahkan oleh peraturan perundang-undangan yang lebih tinggi, yaitu Undang-Undang. Undang-Undang mempunyai kedudukan yang lebih tinggi dari Keputusan Menteri. Sehingga, penerapannya harus mengacu kepada peraturan yang lebih tinggi, yaitu Undang-Undang.

Dalam hierarki peraturan perundang-undangan, UU No 13 Tahun 2003 tentang Ketenagakerjaan dan Putusan Mahkamah Konstitusi No 37 /PUU-IX/2011 yang sifatnya final dan mengikat lebih tinggi posisi dan kedudukannya dari Kepmenaker No 150 Tahun 2000 dan peraturan pelaksana yang lain. Sehingga, jika terjadi penafsiran hukum yang berbeda terhadap suatu hal dalam aturan-aturan tersebut, maka acuannya harus mengacu kepada peraturan perundang-undangan yang lebih tinggi.

\section{E. Kesimpulan}

Berdasarkan pembahasan yang telah diuraikan sebelumnya, maka dapat ditarik 3 (tiga) kesimpulan yaitu sebagai berikut :

1. Dalam Pasal 155 ayat 2 UU Ketenagakerjaan dinyatakan bahwa, "Selama putusan lembaga penyelesaian perselisihan hubungan industrial belum ditetapkan, baik Pengusaha maupun Pekerja/Buruh harus tetap melaksanakan segala kewajibannya."

Dalam hal menunggu penetapan dari Pengadilan, Pasal 155 ayat 2 UU Ketenagakerjaan ini mengandung pengertian bahwa sebelum adanya putusan 
pengadilan yang memperoleh kekuatan hukum tetap tentang penetapan Pemutusan Hubungan Kerja, maka buruh tetap menyelesaikan kewajibannya seperti biasa yakni bekerja dan menerima gaji, begitu juga Pengusaha wajib menyelesaikan kewajibannya seperti biasa pula yakni memberi gaji pada buruh dan menjalankan roda usahanya seperti biasa.

2. Dalam prakteknya, terdapat putusan Hakim yang berbeda-beda terkait pemberian upah proses kepada pekerja, yaitu upah proses sebanyak 6 (enam) bulan upah, lebih dari 6 (enam) bulan upah dan tidak memberikan upah proses.

Putusan Hakim yang memberikan upah proses sebanyak 6 (enam) bulan upah didasarkan pada Kepmenaker No 150 Tahun 2000 tentang Penyelesaian Pemutusan Hubungan Kerja Dan Penetapan Uang Pesangon, uang Penghargaan Masa Kerja Dan Ganti Kerugian Di Perusahaan.

Putusan Hakim yang memberikan upah proses lebih dari 6 (enam) bulan upah didasarkan pada Pasal 155 ayat 2 UU No 13 Tahun 2003 tentang Ketenagakerjaan dan Putusan MK No 37 Tahun 2011

Putusan Hakim yang tidak memberikan upah proses merupakan putusan yang didasarkan pada kewenangan atau diskresi dari Hakim.

Pertimbangan atau pendekatan Hakim dalam memberikan upah proses dilatarbelakangi oleh pertimbangan atau pendekatan (teori) yang bermacammacam.

Putusan Hakim yang memberikan upah proses sebanyak 6 (enam) atau lebih didasari oleh teori keadilan hukum seperti yang dicetuskan oleh I Dewa Gede Atmadja yang meletakkan keadilan kepada aturan-aturan umum

Putusan Hakim yang tidak memberikan upah proses didasari oleh teori hukum progresif yang dicetuskan oleh Satjipto Rahardjo yang menekankan bahwa keadilan itu untuk masyarakat (luas).

3. Menurut Peneliti, jangka waktu pembayaran upah proses yang memenuhi unsur keadilan adalah sebesar 6 (enam) bulan atau lebih. Hal ini didasarkan pada Kepmenaker No 150 Tahun 2000 yang menyatakan upah proses diberikan sebanyak 6 (enam) bulan upah. Akan tetapi, jika penyelesaiannya melebihi 6 (enam) bulan, maka penentuan upah proses mengacu kepada Pasal 155 ayat 2 UU No 13 Tahun 2003 tentang Ketenagakerjaan juncto Putusan MK No 37 Tahun 2011 yaitu upah proses dibayarkan sampai adanya putusan yang berkekuatan hukum tetap.

Undang-Undang Nomor 13 Tahun 2003 tentang Ketenagakerjaan dan UndangUndang Nomor 2 Tahun 2004 tentang Penyelesaian Perselisihan Hubungan Industrial mengatur mengenai upah yang harus dibayarkan oleh selama proses pemutusan hubungan kerja kepada pekerja (upah proses), akan 
tetapi undang undang tersebut maupun peraturan pelaksanaannya tidak mengatur sampai kapan upah proses tersebut harus dibayar.

Putusan Mahkamah Konstitusi No 37 Tahun 2011 juga telah memberikan penafsiran terhadap Pasal 155 ayat 2 UU No 13 Tahun 2003 tentang Ketenagakerjaan yang dalam putusannya berisi bahwa upah proses harus dibayarkan sampai dengan adanya putusan yang berkekuatan hukum tetap. Dengan adanya putusan Mahkamah Konstitusi tersebut, maka Pasal 16 Kepmenakertans No 150 Tahun 2000 yang menyatakan pemberian upah proses sebanyak enam bulan upah tersebut bertentangan dengan Putusan Mahkamah Konstitusi No 37 Tahun 2011. Sehingga, berdasarkan ketentuan Pasal 191 UU No 13 Tahun 2003 tentang Ketenagakerjaan, seharusnya Pasal 16 Kepmenakertans No 150 Tahun 2000 tersebut tidak berlaku lagi. Namun, faktanya dalam putusan Hakim Mahkamah Agung, Hakim mendasarkan putusannya pada Pasal 16 Kepmenakertans No 150 Tahun 2000 yang memberikan upah proses sebanyak 6 (enam) bulan upah.

Rekomendasi Peneliti dari pembahasan diatas adalah mematuhi hukum positif yang berlaku yaitu melaksanakan perintah Undang-Undang dengan membayar upah proses sampai putusan mempunyai kekuatan hukum tetap (inkracht van gewijsde) dengan berdasar kepada Pasal 155 ayat 2 UU No 13 Tahun 2003 tentang Ketenagakerjaan dan Putusan Mahkamah Konstitusi Nomor 37/PUU-IX/2011. Hal ini harus menjadi perhatian oleh para Hakim yang memutuskan perkara dilapangan. Bukan hanya para Hakim dipengadilan tingkat pertama, Hakim Mahkamah Agung juga harus mempunyai pendirian yang sama dengan mengeluarkan Surat Edaran pada jajarannya, sehingga mempunyai keseragaman pandangan terhadap putusan perkara yang sama. 


\section{Buku}

\section{DAFTAR PUSTAKA}

Adrian Sutedi, Hukum Perburuhan, Jakarta: Sinar Grafika, 2011.

Ahmad Kamil, Filsafat Kebebasan Hakim, Jakarta: Kencana Prenada Pratama, 2012.

Amiruddin, Pengantar Metode Penelitian Hukum, Jakarta: PT Raja Grafindo Persada, 2012.

Bambang Sunggono, Metode Penelitian Hukum, Jakarta: Rajagrafindo Persada, 2007.

I Dewa Gede Atmadja, Filsafat Hukum, Jakarta : Setara Press.

Janus Sidabalok, Hukum Perusahaan, Analisis Terhadap Pengaturan Peran Perusahaan Dalam Pembangunan Ekonomi, Bandung: Nuansa Aulia, 2012.

J. Djohansjah , Reformasi Mahkamah Agung Menuju Independensi Kekuasaan Kehakiman, Jakarta, Kesaint Blanc, 2008.

Kahar Masyhur, Membina Moral Dan Akhlak, Jakarta: Kalam Mulia, 1985.

M. Yahya Harahap, Pembahasan Permasalahan Dan Penerapan KUHAP, Jakarta: Sinar Grafika

Satjipto Rahardjo, Membedah Hukum Progresif, Jakarta: Kompas, 2007, hal 154

Soerjono Soekanto, Pengantar Penelitian Hukum, Jakarta: UI Press, 1986.

Syahrizal Abbas, Mediasi Dalam Perspektif Hukum Syariah, Hukum Adat Dan Hukum Nasional, Jakarta: Kencana, 2009.

\section{Peraturan Perundang - Undangan}

Kepmenaker No 150 Tahun 2000 tentang Penyelesaian Pemutusan Hubungan Kerja Dan Penetapan Uang Pesangon, Uang Penghargaan Masa Kerja Dan Ganti Kerugian Di Perusahaan

Kitab Undang-Undang Hukum Acara Pidana

Kitab Undang-Undang Hukum Perdata

Putusan Mahkamah Konstitusi No 37/PUU-IX/2011

Surat Edaran Mahkamah Agung RI No 3 Tahun 2015 tentang Pemberlakuan Rumusan Hasil Rapat Pleno Kamar Mahkamah Agung Tahun 2015 Sebagai Pedoman Pelaksanaan Tugas Bagi Pengadilan 
Undang-Undang Nomor 13 Tahun 2003 Tentang Ketenagakerjaan

Undang-Undang Nomor 2 Tahun 2004 Tentang Penyelesaian Perselisihan Hubungan Industrial

Undang-Undang Nomor 48 Tahun 2009 Tentang Kekuasaan Kehakiman 